\title{
PENGAMBILAN ZAT WARNA ALAMI DARI BUAH MANGROVE SPESIES RHIZOPHORA MUCRONATA UNTUK PEWARNA BATIK RAMAH LINGKUNGAN
}

\author{
Paryanto*), Endang Kwartiningsih, Wusana Agung W, Sunu H Pranolo, Vicka \\ Haningtyas, Ryan Hidayat, Ilham Roy $S$ \\ Jurusan Teknik Kimia Fakultas Teknik Universitas Sebelas Maret \\ ${ }^{*}$ E-mail: paryanto.uns@gmail.com
}

\begin{abstract}
Abstrak
Indonesia memiliki lahan mangrove seluas 4,255 juta ha, termasuk yang terluas di dunia. Salah satu species yang banyak tumbuh di lahan mangrove adalah Rhizophora mucronata. Potensi tanaman mangrove di Bontang sebagai bahan baku pewarna alami cukup memadai. Luas tanam 2.935 ha menempati luasan sekitar $70 \%$ dari lahan yang tersedia. Luasan tersebut, terdapat sekitar 3 juta pohon jenis ini bila dianggap jarak tanam $2 \mathrm{~m} \mathrm{x} 2$ $\mathrm{m}$, dengan anggapan bahwa setiap tahun satu batang pohon spesies ini menghasilkan $50 \mathrm{~kg}$ buah dan $50 \%$ buah tersebut dipergunakan untuk pembibitan maka masih tersedia sebanyak 75.000 ton buah sebagai bahan baku pewarna alami. Apabila perolehan proses ini sebesar 5\% maka berpotensi diperoleh pewarna alami sebanyak 3.750 ton. Pada penelitian ini pengambilan zat warna alami dari buah mangrove spesies Rhizopora mucronata dilakukan dengan proses ekstraksi menggunakan pelarut air pada perbandingan massa bahan terhadap pelarut $1: 10$, suhu $100{ }^{\circ} \mathrm{C}$ selama 60 menit. Zat warna tersebut kemudian dipekatkan dengan proses evaporasi hingga volume tinggal $30 \%$. Selanjutnya ekstrak dimanfaatkan untuk pewarnaan pada kain batik. Pada penelitian ini dipelajari pengaruh jumlah pencelupan : 5 kali, 7 kali, dan 10 kali terhadap hasil pewarnaan pada kain. Selain itu dipelajari juga pengaruh larutan fixer terhadap hasil pewarnaan pada kain. Larutan fixer yang digunakan pada percobaan ini yaitu tawas, kapur tohor dan tunjung. Untuk kain yang dicelupkan pada fixer tawas, memberikan warna yang lebih muda. Pencelupan zat warna dengan fixer kapur tohor memberikan warna coklat, sesuai warna asli ekstrak buah mangrove dan fixer dengan tunjung memberikan warna kehitaman.
\end{abstract}

Kata kunci: Buah Mangrove, ekstraksi, tanin, Rhizophora mucronata, batik

\begin{abstract}
Indonesia's mangrove area is 4.255 million ha, included as the one of the widest on earth. One of the mangrove species that grows mostly in Indonesia is Rhizophora mucronata. The potention of mangrove plants in Bontang is sufficient to be used as a main substance of natural coloring matters. Plantation area of 2,935 ha for Rhizophora mucronata is reaching 70\% of the total available area. Within this area, there is about 3 million trees of this species and if the planting distance is assumed $2 \mathrm{~m} \times 2 \mathrm{~m}$, with an assumption that every single tree of this species produces $50 \mathrm{~kg}$ fruits and 50\% of that fruits are used as a seeding, there are 75,000 tons of the fruits still available as a main substance of natural coloring matters. If the result of this process is 5\%, the natural coloring matters obtained is about 3,750 tons. On this research the acquisition of the natural coloring matters from mangrove fruits is carried out using extraction process with water solute and the ratio between materials and water is $1: 10$, at the temperature $100{ }^{\circ} \mathrm{C}$ within 60 minutes. The coloring matters is then concentrated using evaporation process until the volume is $30 \%$ left. After that, the extract is then used to color the batik fabrics. On this research, the effects of various times of dipping (5, 7, and 10 times) to the color resulted is studied. Besides that, the effect of fixer solutions to the color resulted is also studied. Fixer solutions that is used in this research are alums, dried up limes, and lotus. The fabrics that dipped into the alums fixer, resulting a bright brown color. The fabrics that dipped in to the dried up limes fixer, resulting a true brown color, same as the original extract color and the one that dipped into the lotus fixer is resulting a dark color.
\end{abstract}

Keywords: Mangrove Fruit, extraction, tannin, Rhizophora mucronata, batik 


\section{PENDAHULUAN}

UNESCO telah memberikan pengakuannya terhadap produk batik di Indonesia, dan pada awal bulan Oktober 2011 telah diadakan pameran batik di Jakarta Convention Center di Jakarta yang diikuti oleh beberapa negara. Pada kesempatan tersebut Menteri Perindustrian dan Perdagangan menyerahkan blue print kepada Presiden RI yang berisi tentang kurangnya infrastruktur batik, salah satunya adalah penyediaan pewarna alami batik. Perkembangan industri pengolahan pangan, sandang, kosmetik, dan farmasi serta terbatasnya jumlah pewarna alami menyebabkan penggunaan pewarna sintetik meningkat. Sejak penemuan pewarna sintetik, penggunaan pigmen sebagai pewarna dari bahan alam semakin menurun, meskipun keberadaannya tidak menghilang sama sekali. Pewarna sintetis memang terbukti lebih murah sehingga lebih menguntungkan dari segi ekonomis, tetapi penggunaannya sebagai pewarna makanan, minuman dan pakaian dapat berdampak negatif yaitu penyebab toksik dan karsinogenik karena kandungan logam berat dalam pewarna sintetik tidak dapat dihancurkan dalam sistem pencernaan manusia dan akan terakumulasi di dalam tubuh.

(http://www.depkes.go.id).

Penggunaan pewarna alami khususnya untuk batik atau tekstil (pakaian) sangat perlu digalakkan karena lebih aman dari segi kesehatan. Pilihan warnanya memang agak terbatas dibandingkan dengan pewarna sintetis, maka perlu pengembangan melalui berbagai penelitian terutama untuk pencarian sumber bahan pewarna alami yang berasal dari tanaman setempat. Tanaman yang mengandung pewarna alami banyak tersedia, misalnya limbah kulit kopi, kesumba/ galenggem (bixa orelana), jati, soga, ulin, pinang, limbah sawit, berbagai jenis mangrove dan masih banyak yang tersebar di seluruh Indonesia. Pengembangan pewarna alami ini sebagai salah satu unggulan di Program Studi Teknik Kimia UNS dengan telah diresmikannya Pusat Studi Zat Warna Alami oleh Dirjen DIKTI dan didukung oleh BKK-PII yang telah tercakup dalam visi misi program studi Teknik Kimia UNS. Penelitian tentang pengambilan zat warna alami dari tanaman telah banyak dilakukan di Program Studi Teknik Kimia UNS antara lain pengambilan secara batch zat warna alami dari kunyit (kuning), jati (coklat merah), daun suji dan pandan (hijau), nanas (kuning), jarak (hijau), soga (kuning), aren (coklat), ulin (coklat tua) pinang (merah tua), bunga teleng (biru), jelaga/ arang (hitam), kesumba/galenggem (merah) dan khususnya buah tanaman mangrove jenis Rhizophora mucronata (coklat merah) yang banyak terdapat di daerah Bontang, Kalimantan Timur. Indonesia memiliki lahan hutan mangrove terluas di dunia (4,225 juta ha atau $23 \%$ luas lahan hutan mangrove dunia) melebihi Brasil, Nigeria dan Australia (Spalding, M.F., 1997). Kota Bontang di Kalimantan Timur terletak pada $0,137^{\circ} \mathrm{LU}$, $117,5^{\circ}$ BT yang berbatasan dengan Kabupaten Kutai Timur di sebelah utara dan barat, Kabupaten Kutai Kartanegara di sebelah selatan dan Selat Makasar di sebelah timur. Luasnya sekitar 49.752,56 ha dan memiliki lahan tanam mangrove seluas 2.935 ha $(5,9 \%)$ dengan 1.715 ha merupakan lahan blok perlindungan tanaman (Gambar 1). Sejumlah jenis tanaman mangrove terdapat di Kota Bontang, antara lain Sonneratia ovata, Bruguiera gymnorrhiza, Lumnitzera racemosa, Lumnitzera littorea, Acanthus ilicifolius, Avicenniaceae, Nypa fruticans, Xylocarpus granatum, dan Rhizophora mucronata. Selain sebagai fungsi perlindungan pantai dari abrasi, beberapa jenis diantaranya telah banyak dimanfaatkan masyarakat sebagai sumber bahan makanan, misalnya Sonneratia ovata untuk sirup dan Bruguiera gymnorrhiza untuk tepung sehingga sistem pembudidayaan dan pe- ngembangbiakan telah terbentuk. Jenis Rhizophora mucronata (Gambar 2) menempati luas lahan tanaman terbanyak yaitu sekitar $70 \%$ dari keseluruhan blok perlindungan, tetapi relatif belum banyak diketahui nilai tambahnya selain sebagai pelindung pantai dari abrasi. Dari luasan tersebut, diduga terdapat 3.000 .000 pohon jenis ini bila dianggap jarak tanam $2 \mathrm{~m} \times 2 \mathrm{~m}$. Tanaman jenis ini bercirikan khusus daun lebih besar dari pada Rhizophora stylosa, pada bagian tengah memiliki panjang yang maksimum 
dan benang sari pendek. Dengan anggapan bahwa setiap tahun satu batang pohon spesies Rhizophora mucronata menghasilkan $50 \mathrm{~kg}$ buah dan $50 \%$ buah tersebut dipergunakan untuk pembibitan maka masih tersedia sebanyak
75.000 ton buah sebagai bahan baku pewarna alami. Apabila perolehan proses ini sebesar 5\%, maka berpotensi diperoleh pewarna alami sebanyak 3.750 ton.

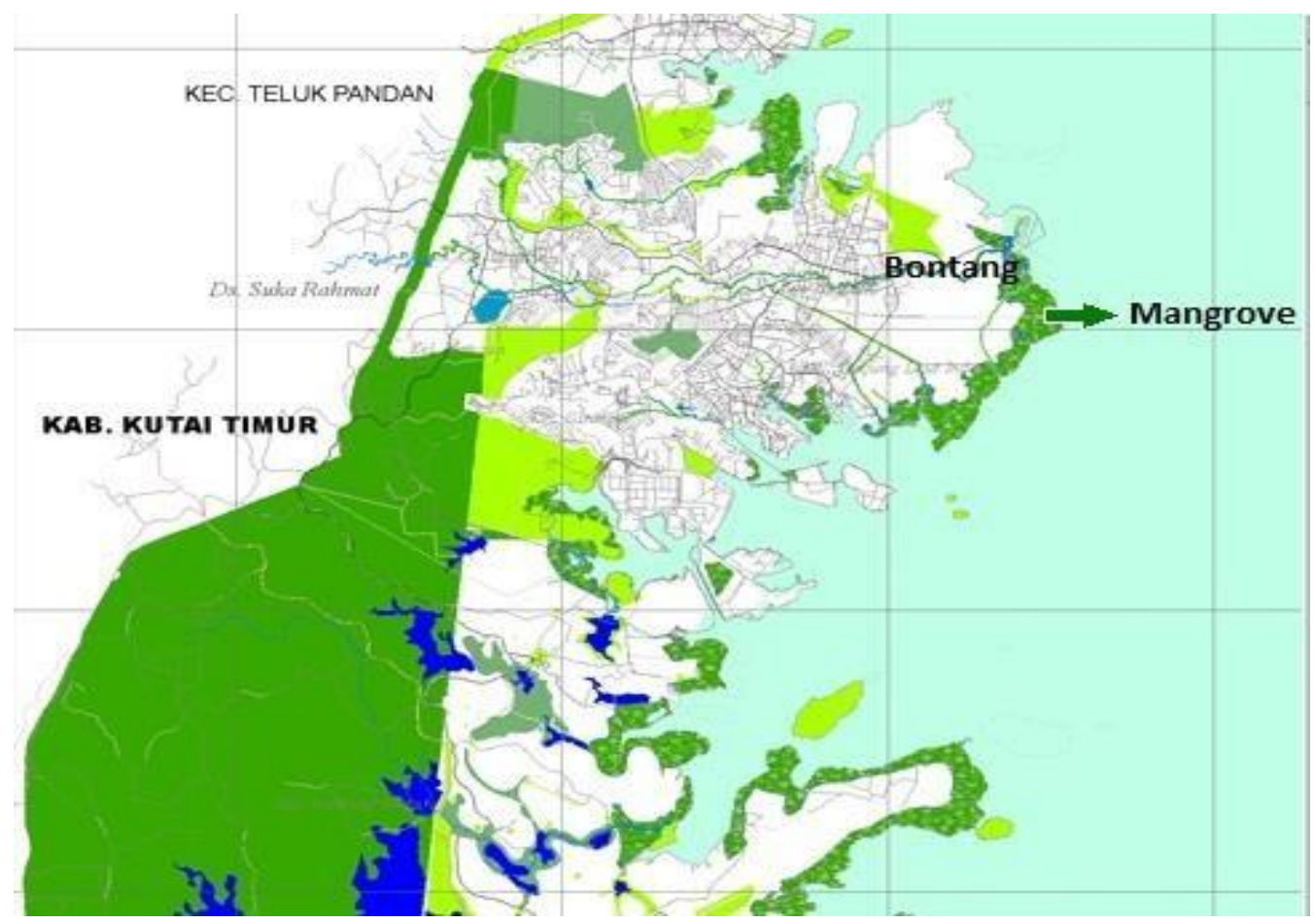

Gambar 1. Lahan mangrove di Bontang
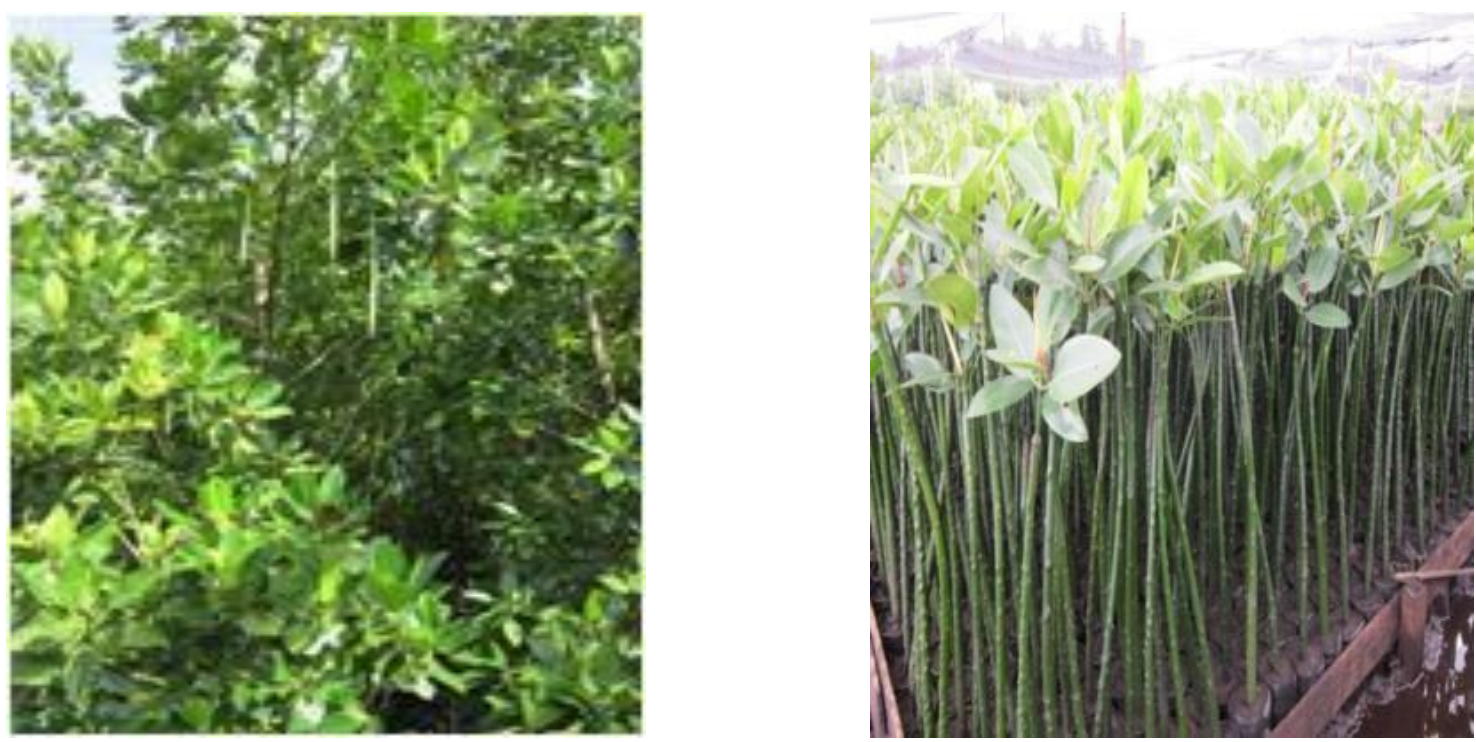

Gambar 2. Rhizophora Mucronata 
Zat warna alami adalah zat warna yang diperoleh dari alam/tumbuhan baik secara langsung maupun tidak langsung. Secara tradisional zat warna alami diperoleh dengan ekstraksi atau perebusan bagian-bagian tanaman antara lain kulit, ranting, daun, akar, bunga, biji atau getah. Zat warna alami mempunyai efek warna yang unik dan khas yang sulit ditiru zat warna sintesis , sehingga merupakan pendukung produk-produk ekslusif dan bernilai seni tinggi. Kelemahan aplikasi pewarna alami khususnya pada tekstil adalah proses pewarnaan memerlukan waktu yang lama, sehingga kecepatan produksinya terbatas. Tanaman merupakan sumber zat warna alami karena mengandung pigmen alam. Potensi ini ditentukan oleh intensitas warna yang dihasilkan dan sangat tergantung pada jenis coloring matter yang ada. Coloring matter adalah substansi yang menentukan arah warna zat warna alami, merupakan senyawa organik yang mengandung lebih dari satu jenis coloring matter. Berdasarkan jenis coloring matter, zat warna alami dibagi menjadi 4 golongan yaitu:

a) Zat warna mordan (alam), kebanyakan zat warna alami tergolong zat warna mordan alam sehingga zat warna alami dapat menempel dengan baik. Proses pewarnaannya harus melalui penggabungan dengan kompleks oksida logam membentuk zat warna yang tidak larut. Zat warna alami golongan ini dapat menjadi sangat tahan, misalnya zat warna alami yang berasal dari kulit akar moridin.

b) Zat warna direk, zat warna ini melekat di serat kain berdasarkan ikatan hidrogen sehingga ketahanannya rendah, misalnya zat warna alami yang berasal dari kunyit (Curcumin).

c) Zat warna asam/basa, zat warna jenis ini mempunyai gugus kombinasi asam dan basa, misalnya flavanoid pigmens.

d) Zat warna bejana, zat warna ini mewarnai serat kain melalui proses reduksi-oksidasi (redoks) dikenal sebagai pewarna yang paling tua di dunia dengan ketahanan yang paling unggul dibandingkan ketiga jenis zat warna alami lainnya, misalnya zat warna alami yang berasal dari daun torn (Indigo).

Kandungan zat warna alami pada tanaman mangrove berupa tanin yang termasuk ke dalam flavanoid pigmens (Rahim, 2007). Penelitian mengenai pengambilan tanin dari tanaman dengan proses ekstraksi sudah banyak dilakukan peneliti. Hasil ekstraksi tanin dari kulit pohon mangrove dengan pelarut etanol $90 \%$ diperoleh yield 22,01\% (Danarto, Y.C., dkk., 2011). Ekstraksi tanin juga pernah dilakukan pada tanaman putri malu (Mimosa pudica) dengan berbagai macam jenis pelarut yang menghasilkan yield maksimal pada pelarut jenis etanol (Marnoto, C., dkk., 2012). Kwartiningsih, E., dkk., (2013), melakukan ekstraksi tanin pada buah mangrove jenis Rhizopora mucronata dengan menggunakan berbagai jenis pelarut (air, etanol, metanol, aseton, n-heksana) pada berbagai variasi suhu dan perbandingan massa buah terhadap volume pelarut. Dari hasil penelitian yang dilakukan, buah mangrove jenis Rhizopora mucronata mengandung zat warna alami berupa tanin sebesar 4,326 mg tanin per gram buah mangrove. Jenis pelarut yang memberikan hasil optimal adalah air dengan perbandingan antara bahan baku dengan pelarut yang baik adalah $1 \mathrm{~kg}$ : 10 liter air. Proses ekstraksi zat warna dilakukan selama 60 menit pada suhu $100{ }^{\circ} \mathrm{C}$.

\section{METODA}

\section{Bahan baku :}

Bahan utama penelitian ini adalah buah mangrove (Rhizophora mucronata) yang diperoleh dari lahan mangrove di Bontang, Kalimantan Timur. Buah mangrove dipotong kecil-kecil dan dikeringkan. Buah mangrove yang telah kering dan dipotong kecil-kecil selanjutnya diekstraksi dalam tangki berpengaduk, menggunakan pelarut air dengan perbandingan massa bahan terhadap pelarut 1 : 10 , suhu $100{ }^{\circ} \mathrm{C}$ selama 60 menit. Rangkaian alat ekstraksi dan evaporasi dapat dilihat pada Gambar 3. 
Alat:

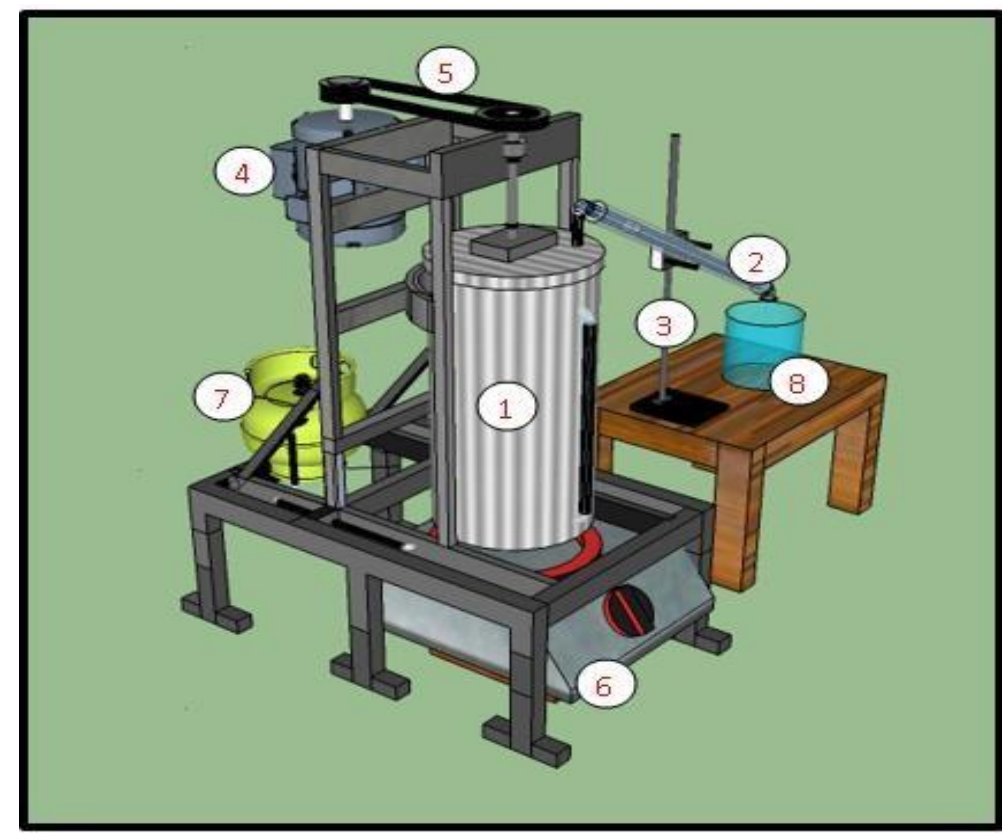

Gambar 3. Rangkaian Alat Ekstraksi dan Evaporasi

1. Rangkaian alat ekstraksi dan evaporasi

2. Pendingin balik

3. Statif

4. Motor listrik

5. Belt

6. Kompor gas

7. Gas LPG

8. Gelas beaker

\section{Jalannya Penelitian}

Membuat alat dalam skala pilot plan, melakukan proses ekstraksi dengan cara memasukkan bahan baku mangrove sejumlah $1 \mathrm{~kg}$ kedalam alat ekstraktor no1 ditambahkan solven berupa air sebanyak 10 L, dipanaskan dengan kompor No 7 menggunakan bahan bakar LPG No 6, motor pengaduk no 4 dijalankan, proses ekstraksi pada suhu $100{ }^{\circ} \mathrm{C}$ selama 60 menit. Zat warna yang diperoleh kemudian dipekatkan dengan proses evaporasi hingga volume tinggal $30 \%$. Selanjutnya ekstrak dimanfaatkan untuk pewarnaan pada kain batik. Pada penelitian ini dipelajari pengaruh jumlah pencelupan : 5 kali, 7 kali, dan 10 kali terhadap hasil pewarnaan pada kain. Selain itu dipelajari juga pengaruh larutan fixer (pengunci) terhadap hasil pewarnaan pada kain. Larutan fixer yang digunakan pada percobaan ini yaitu tawas, kapur tohor dan tunjung.

\section{HASIL DAN PEMBAHASAN}

\section{Perancangan, Pabrikasi Skala Pilot Plant.}

Kecepatan produksi, peningkatan kapasitas produksi dan kualitas/keseragaman produk diperlukan dalam rangka produksi pewarna alami bagi unit usaka kecil menengah. Peralatan produksi pewarna alami magrove terdiri atas alat potong (cutter) buah mangrove dan alat ekstraksi yang sekaligus berfungsi sebagai evaporator untuk menghasilkan konsentrat pewarna alami mangrove (Gambar 4). Sebagian besar material alat menggunakan jenis stainless steel. Pabrikasi peralatan dilaksanakan di salah satu bengkel 
mesin di Kabangan Surakarta. Peralatan potong menggunakan motor listrik $1 \mathrm{hp}$ untuk menghasilkan produk potongan buah mangrove ukuran di bawah $1 \mathrm{~cm}$ dengan kecepatan produksi sekitar $20-30 \mathrm{~kg} / \mathrm{jam}$. Tangki ekstraksi berkapasitas $10 \mathrm{~L}$ dilengkapi dengan pengaduk yang berputar dengan kecepatan rendah menggunakan motor listrik $0,5 \mathrm{hp}$ dan peralatan pemanas berbahan bakar LPG. Peralatan ekstraksi sekaligus digunakan sebagai evaporator untuk menghasilkan konsentrat pewarna alami mangrove dengan kapasitas produksi mencapai $20 \mathrm{~L} /$ hari. Saat ini peralatan pembuat pewarna alami dari buah mangrove skala pilot plant tersebut telah berhasil dipabrikasi dan sudah terpasang di Laboratorium Aplikasi Teknik Kimia UNS. Pembuatan zat warna alami dilakukan pada kondisi suhu $100{ }^{\circ} \mathrm{C}$, perbandingan bahan terhadap solven adalah $1 \mathrm{~kg}$ bahan mangrove, 10 liter air selama 60 menit kemudian dipekatkan menjadi $30 \%$ nya sekitar 3 liter. Skema proses pembuatan konsentrat pewarna alami dari buah mangrove spesies Rhizophora mucronata disajikan pada Gambar 4 sebagai berikut:

(a)
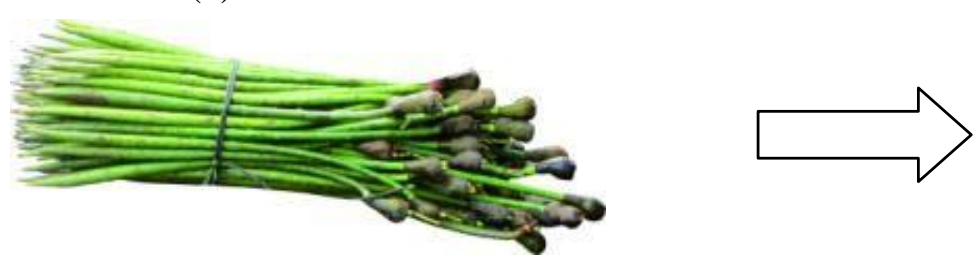

(d)
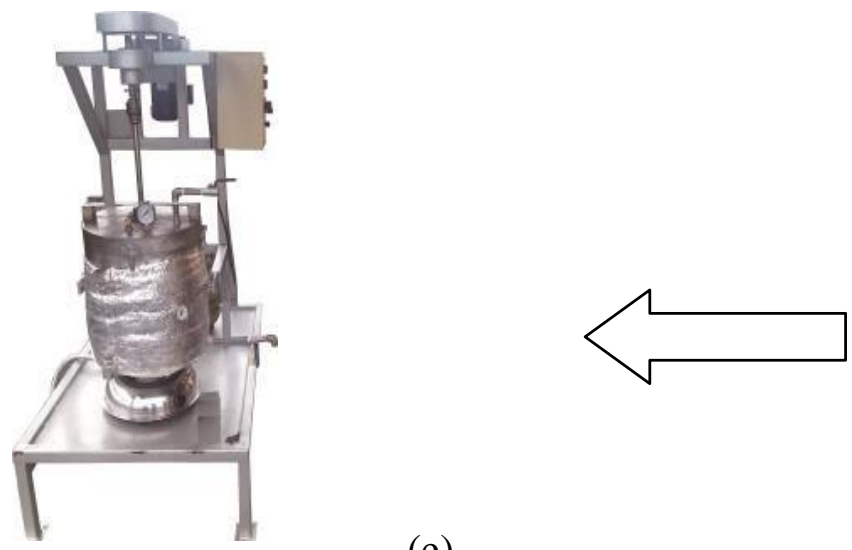

(b)

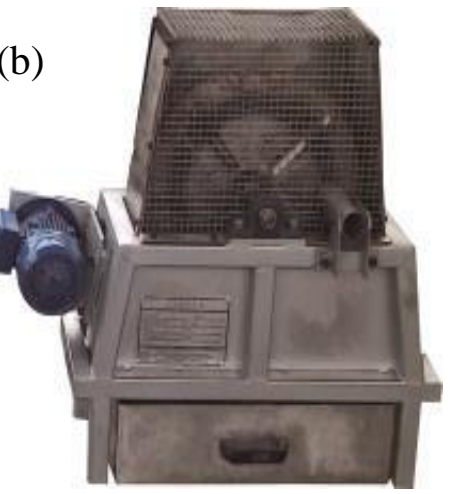

(e)

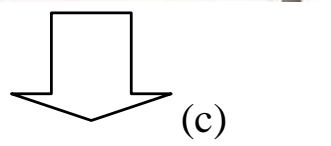

$1 y$

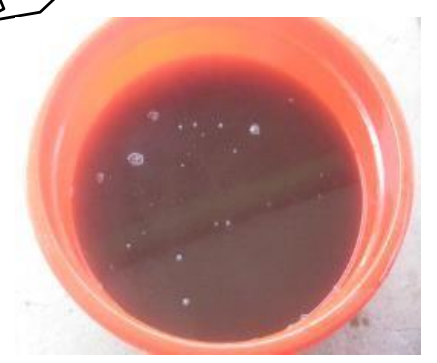

Gambar 4. (a) bahan baku buah mangrove,

(b) alat potong (cutter),

(c) hasil potongan buah mangrove,

(d) alat ekstraksi-evaporasi,

(e) konsentrat pewarna alami mangro 


\section{Pembuatan Pewarna Alami}

Tujuan pelaksanaan pembuatan pewarna alami dari Buah Mangrove (Rhizophora mucronata) ini antara lain memberikan pemahaman kepada para mahasiswa D3 dan S1 untuk penyelesaian Tugas Akhir dan Skripsi. Hasil penelitian diperoleh pewarna alami dengan konsentrat tinggi yang diaplikasikan pada kain batik. Pembuatan pewarna alami dapat dilihat pada Gambar 5.

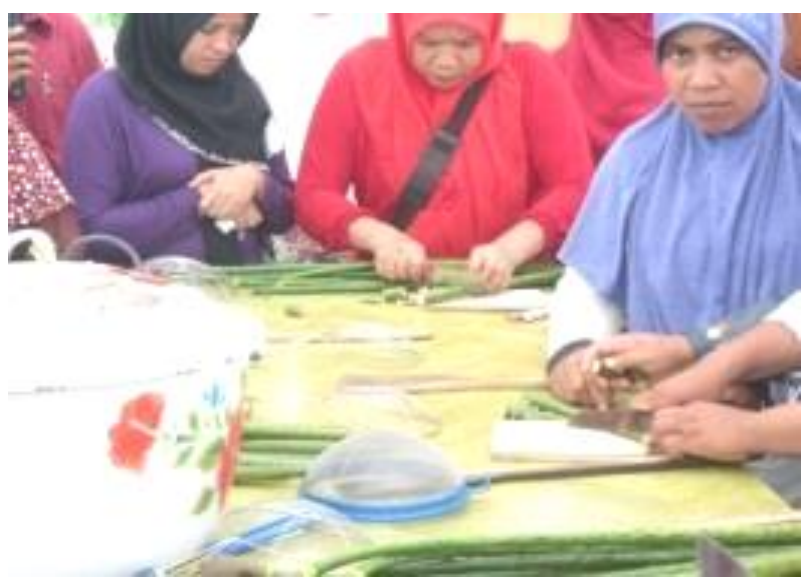

(a)

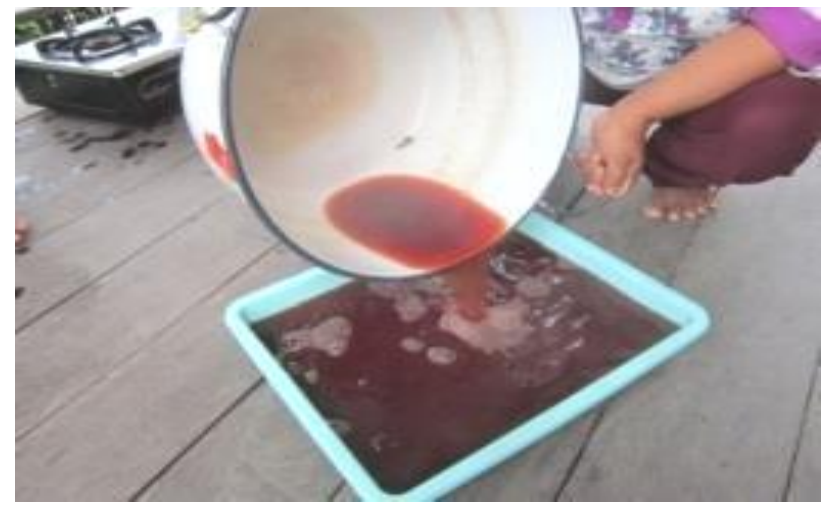

(b)

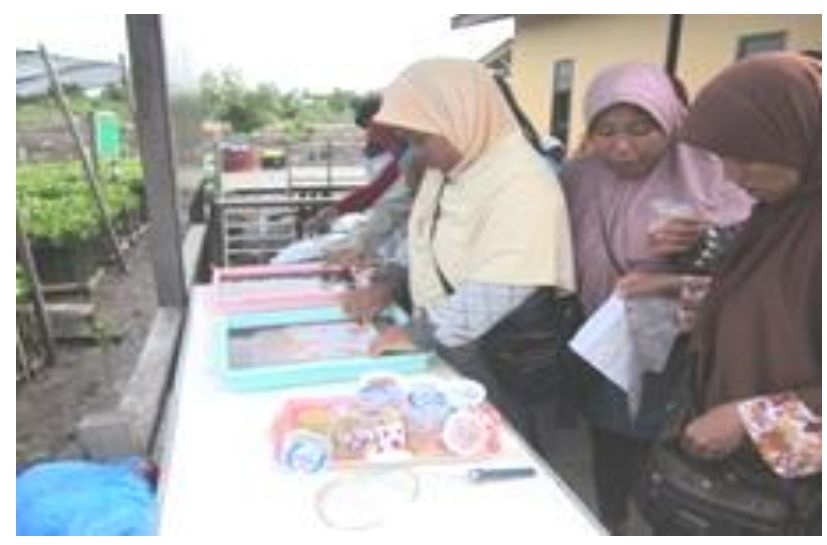

(c)

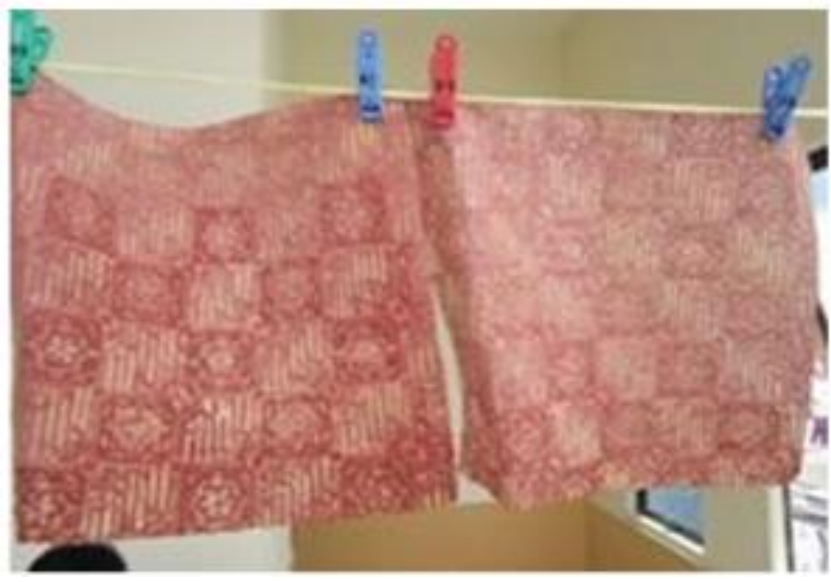

(d)

Gambar 5. Pembuatan Pewarna Alami

(a) Penanganan awal mangrove

(b) Hasil konsentrat pewarna mangrove

(c) Pewarnaan kain

(d) Kain hasil pewarnaan

\section{Membatik dan Mewarna Batik}

Penelitian ini diwujudkan dalam bentuk Pelatihan Aplikasi Pewarna Alami dari Buah Mangrove (Rhizophora mucronata) untuk pewarna batik khas Surakarta. Tujuan kegiatan ini antara lain memberikan pemahaman kepada para mahasiswa mengenai potensi batik khas Surakarta berpewarna alami mangrove sebagai salah satu kearifan lokal dan komoditas ekonomi, dan memberikan bekal keterampilan kepada mahasiswa mengenai proses pembuatan batik deangan pewarna alami mangrove dimulai dari pembuatan motif batik sampai dengan finishing kain.

Rangkaian kegiatan meliputi praktik pembuatan pola/ motif batik tulis dan cap, praktik penanganan awal kain (pencucian dan mordanting), praktik pewarnaan kain (pencelupan ke dalam pewarna alami dilakukan 5 kali, 7 kali, dan 10 kali pencelupan), praktik fiksasi/ penguncian warna pada kain (tawas, kapur, dan tunjung). Praktik pembuatan batik dapat dilihat pada Gambar 6. 


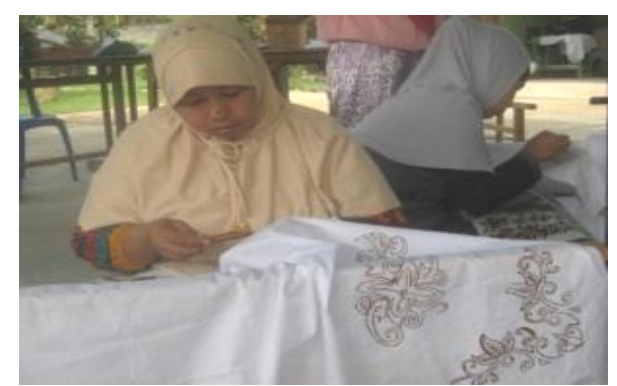

(a)

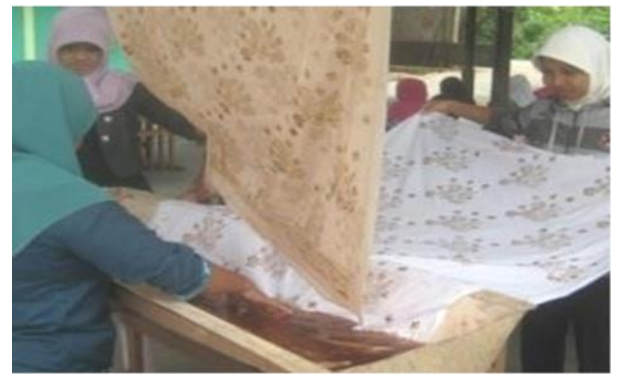

(c)

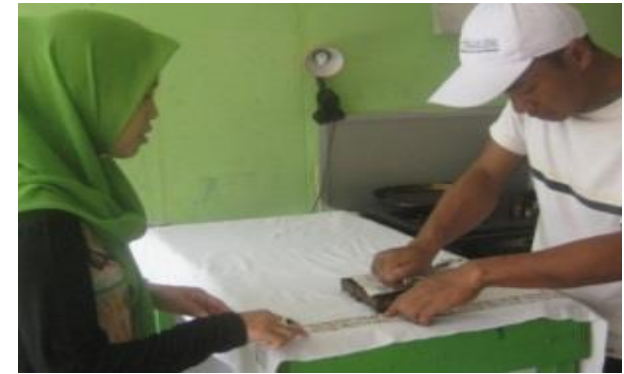

(b)

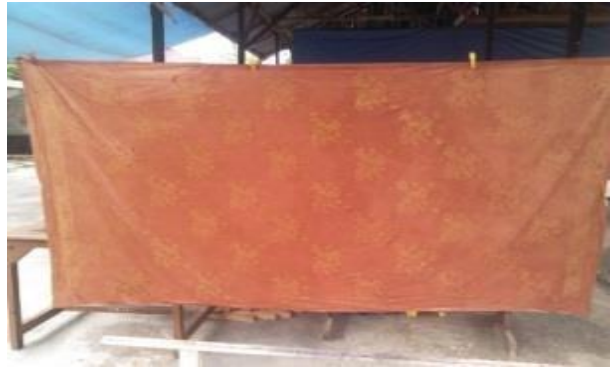

(d)

Gambar 6. Proses Pembuatan Batik
(a) Pembuatan Motif
(c) Pencelupan
(b) Printing
(d) Penjemuran

\section{KESIMPULAN}

Pada penelitian ini dapat diambil kesimpulan bahwa zat warna alami dari buah mangrove diekstraksi menggunakan pelarut air dalam kondisi maksimum dicapai pada perbandingan massa bahan terhadap pelarut $1: 10$, suhu $100^{\circ} \mathrm{C}$, waktu 60 menit, dan ekstrak 30\%. Jumlah pencelupan 5 kali, 7 kali, dan 10 kali terlihat bahwa pencelupan semakin banyak warna yang dihasilkan semakin tajam. Hasil penguncian dengan tawas memberika warna coklat muda. Pencelupan zat warna dengan fixer kapur tohor memberikan warna coklat, sesuai warna asli ekstrak buah mangrove dan fixer dengan tunjung memberikan warna kehitaman.

\section{DAFTAR PUSTAKA}

Danarto, Y.C. dkk., 2011. Pemanfaatan Tanin dari Kulit Bakau sebagai Pengganti Gugus Fenol pada Resin Fenol Formaldehid. Prosiding Seminar Nasional Kejuangan, No. ISSN 1693 4393.
Kwartiningsih, E., Paryanto, Wibowo, W.A., Masturi, E., Jati, A.K., dan Santoso, D.P. 2013. Ekstraksi Tanin dari Buah Mangrove (Rhizophora mucronata). Prosiding Simposium RAPI XII, Fakultas Teknik UMS. No. ISSN 1412-9612.

Marnoto, C. 2012. Ekstraksi Tanin sebagai Bahan Pewarna Alami dari Tanaman Putri Malu (Mimosa pudica) Menggunakan Pelarut Organik. Jurnal Reaktor, 14(1).

Rahim, A.A., et.al. 2007. Mangrove's Tannins and Their Flavanoid MoNomors as Alternative Steel Corrosion Inhibitors in Acidic Medium. Corrosion Science. 49. 402-417.

Spalding, M.F. 1997. World Mangrove Atlas. West Yorshire. The International Society for Mangroves Ecosystems, the World Conservation Monitoring Centre and the International Timber Organization.

http://www.depkes.go.id 